\title{
Integrating monitoring, expert knowledge and habitat management within conservation organisations for the delivery of the water framework directive: A proposed approach
}

\author{
Marc Naura ${ }^{1, *}$, David Sear ${ }^{1}$, Mario Álvarez² ${ }^{2}$ Francisco Peñas², Diego Fernández² and José \\ Barquín ${ }^{2}$
}

${ }^{1}$ School of Geography, University of Southampton, Southampton, SO17 1BJ, UK.

${ }^{2}$ Environmental Hydraulics Institute (IH Cantabria). E.T.S.I. Caminos, Canales y Puertos, Universidad de Cantabria, Avda. de los Castros s/n 39005, Santander, Spain.

*Corresponding author: marc.naura@ soton.ac.uk

Received: 30/4/2010

Accepted: $14 / 4 / 2011$

\begin{abstract}
Integrating monitoring, expert knowledge and habitat management within conservation organisations for the delivery of the water framework directive: A proposed approach

There is a growing necessity to better understand the nature of the relationships between environmental attributes and freshwater species/communities to enable meaningful action to take place against the impacts of environmental change in river ecosystems. Such understanding would need to be based on the investigations of causal relationships rather than the study of statistical correlations or the use of expert opinion as is generally the case. Another issue is in identifying the scale(s) at which process and features should be recorded and assessed to enable the design of relevant monitoring programs. In this paper, we present a short review of existing knowledge on species/habitat relationships and discuss the importance of adequate theoretical frameworks for identifying environmental features of importance to wildlife and determining the scale/s at which they should be assessed. We further propose an approach for eliciting those relationships within the context of monitoring and management practice in conservation organisations. We show how conceptual models of habitat-species relationships can be built using existing knowledge and expert opinion and tested on data collected as part of existing monitoring programs. We suggest such framework, if applied, could not only help identify causal relationships between species, features and processes acting at various scales, but also initiate a knowledge acquisition process within organisations responsible for the delivery of the Water Framework Directive.
\end{abstract}

Key words: River habitats, spatial scale, monitoring strategy, ecological modelling, Water Framework Directive.

\section{RESUMEN}

Integrando seguimiento, conocimiento experto y gestión del hábitat con las organizaciones conservacionistas para la conseguirla Directiva Marco del Agua: Una propuesta de aproximación

Existe una creciente necesidad de entender mejor la naturaleza de las relaciones entre los atributos ambientales y las comunidades/especies de agua dulce para poder desarrollar acciones apropiadas que minimicen el impacto del cambio ambiental en los ecosistemas fluviales. Tal entendimiento necesitaría estar basado en investigaciones de relaciones causales más que en estudios de correlaciones estadísticas, como se acostumbra. Otro aspecto es la identificación de la escala a la cual los procesos y las características deben ser medidas para permitir un diseño de programas de monitoreo relevante. En este artículo se presenta una breve revisión de los conocimientos existentes sobre las relaciones especies/hábitat y se discuten los marcos teóricos existentes para la identificación de las características ambientales de importancia para la fauna y la determinación de la escala/s a la que deben evaluarse. Asimismo, proponemos un método para utilizar esas relaciones en el contexto de la supervisión y las prácticas de gestión en las organizaciones de conservación. Mostramos como modelos conceptuales de relaciones entre hábitats y especies pueden ser construidos usando el conocimiento existente y la opinión de expertos y como pueden ser testados utilizando datos recogidos como parte de los programas de monitoreo en las instituciones encargadas de la conservación. Sugerimos que tal marco, si aplicado, podría no sólo ayudar a identificar relaciones causales 
entre especies, características y procesos actuando a varias escalas, sino también para iniciar un proceso de adquisición de conocimiento en las instituciones responsables de la implementación de la Directiva Marco del Agua.

Palabras clave: Hábitat fluvial, Escala espacial, Estrategia de seguimiento, Modelación ecológica, Directiva Marco del Agua.

\section{INTRODUCTION}

The Water Framework Directive requires European member states to monitor, assess and improve/protect the quality of rivers (European Union, 1992; European Union, 2000) for macrophytes, algae, invertebrates and fish. To do so, member states need to identify habitat features and processes of importance to wildlife so as to enable the assessment of habitat quality, the identification of pressures and impacts and the design of adequate restoration schemes and programmes of measures. It implies an understanding of the relevance of features and processes to the biology of species.

This understanding has generally been built upon studies looking at statistical relationships between micro, meso and macro-scale habitat features, environmental attributes and species occurrence or densities (Rathert et al., 1999; Argent et al., 2003; Feist et al., 2003; Heino et al., 2003; Townsend et al., 2003; McRae et al., 2004). More rarely has it been based on controlled experiments in the lab or mesocosms where environmental conditions can be closely monitored over time and causal relationships can be teased out (Mann \& Bass, 1997; Madsen \& Cedergreen, 2002). The difficulty with these experiments is that they are difficult and costly to set up and may not reflect the complexity of interactions between the natural environment and species and communities. Also, it is hard to imagine how the full spectrum of possible combinations of environmental factors and pressures could be recreated and tested in the laboratory or in mesocosm settings. Even if funding streams matched the legislative timescales and kept pace with environmental change, it is still a formidable task.
Another issue is to identify the scale/s at which features and processes should be recorded and assessed (Wiens, 2002). Rivers and streams could be considered as hierarchical systems in which the higher-scale processes impose constraints on features at lower scales (Frissell et al., 1986). Physical habitat characteristics of lotic ecosystems are highly dependent on the geomorphological structure of the basin (Strahler, 1957; Frissell et al., 1986). For instance, channel or catchment slope affects sediment size distribution and hydraulic characteristics in the different river segments of a given basin. Variations in channel morphology or in sedimentation processes also determine distinct morphological units such as riffles and pools. Also, the structure and composition of the substrate (mineral or organic) and the quantity and quality of detritus or periphyton are highly dependent on hydraulic characteristics and can show broad variations within these mesohabitats differentiating, in turn, microhabitats (Buffagni \& Comin, 2000; Eedy \& Giberson, 2007). In the last two decades, several studies have discussed the role of physical habitat characteristics at different scales in determining the distribution of biological communities (Gregory et al., 1991; Carter et al., 1996; Li et al., 2001; Benda et al., 2004; Parasiewicz, 2007). Most of these studies show that fluvial communities (e.g. algae, macroinvertebrate, fish or riparian forest) do not display the same sensitivity with respect to a given physical characteristic, and thus, physical habitat assessment should be carefully done so as to cover all aspects and scales that might influence species and communities.

The identification of causal relationships between habitat features, processes and communities and the scale at which those should be as- 
sessed are two major issues in designing monitoring and management programmes. So far, a significant amount of applied research has concentrated on the study of statistical relationships between species/communities and attributes at a variety of scales, from the micro to the regional (Austin, 2007; Vaughan et al., 2009). In a political and management environment that is cash poor but rich in sometimes unrealistic expectations, their inherent uncertainties have often failed to convince decision-makers to invest into wider schemes of practice or surveys.

As a result, environmental management has often been carried out on the basis of partial information and local expertise (Pullin et al., 2004; Naura, 2005; Pullin \& Knight, 2005) with practitioners relying on intuition, past experience and anecdotal evidence in their decisionmaking (Sutherland et al., 2004). This has led scientists and environmental managers to call for a better integration of science and management practice to promote a shift towards evidencebased decision-making in conservation (Pullin \& Knight, 2001; Sutherland et al., 2004; Sutherland et al., 2006; Vaughan et al., 2009).

More clarity is therefore required on the nature of relationships between habitat features, processes and species/communities at different scales. We believe it is also important that such knowledge is generated within conservation organisations by practitioners and scientists for its successful integration within management practice. Conservation organisations run vast monitoring programs and possess valuable expertise that could potentially be combined in a knowledge management cycle to progress operational practice and spur further research.

We consider this can be achieved using existing structures, resources and monitoring programmes within conservation organisations by: (1) choosing an appropriate theoretical framework enabling the integration of geomorphological processes, disturbances, species and communities at different scales; (2) developing conceptual models using existing data, knowledge and expert opinion describing the nature of those relationships at each scale; (3) designing or complementing existing survey strategies to sup- port all environmental attributes identified in the previous step; and (4) collecting data to test the validity and relevance of the conceptual models and the theoretical framework.

This way we can establish a link between theory, modelling, monitoring and practice and test hypotheses on causal relationships between features and processes acting at various scales within the existing structure and work practice of environmental organisations. This will not only increase practitioners' knowledge of the ecology of catchments but initiate a knowledge acquisition process that is based on theory rather than the need for quick methodological fixes.

In this paper, we will first provide a short review of existing knowledge on the links between species/communities and habitat attributes at different scales and then propose a framework for eliciting those relationships within the context of environmental monitoring and management practice in conservation organisations.

\section{SHORT REVIEW}

\section{Macroinvertebrate communities}

Many researchers have studied the effects that physical characteristics at river basin, segment (e.g. Death \& Joy, 2004), mesohabitat (e.g. Beisel et al., 1998b) and microhabitat scales (e.g. Brooks et al., 2005) have on the structure and composition of macroinvertebrate communities. At catchment scale, macroinvertebrate communities seem to be governed by the geology and the geomorphologic conditions of the basin, which determine the hydraulic characteristics of the river flow and water physicochemical quality (Death \& Joy, 2004; SanchezMontoya et al., 2007). Climatic conditions have also been recognised as another important factor in determining macroinvertebrate spatial and seasonal distribution at a catchment scale as climate affects water temperature (Vannote et al., 1980) and hydrological variability (discharge, floods, and droughts) differentiating, for example, among intermittent and perennial streams (Sanchez-Montoya et al., 2007). 
Death and Joy (2004) found that habitat characteristics measured at a reach scale were better predictors of macroinvertebrate community structure than environmental variables derived from basin geology, geomorphology or land use. Thus, they concluded that physical habitat characteristics such as substrate composition, channel stability or riparian vegetation seemed to have a stronger influence in determining the structure and composition of macroinvertebrate communities than larger scale variables. Richards et al. (1996; 1997) also reported that local reach-scale characteristics (e.g. substrate type, stream width and canopy cover) were better descriptors of macroinvertebrate community composition and species traits than catchment-scale variables (e.g. geology and land use), although the opposite results have also been reported (Corkum, 1989).

Further, several taxa such as Simulium, Hydropsyche or Heptageniidae have been largely related to microhabitats with high water velocity and hydraulic stress, while other taxa such as several molluscs follow the opposite pattern (Giller \& Malmqvist, 1997; Merigoux \& Doledec, 2004; Eedy \& Giberson, 2007; Sagnes et al., 2008). Thus, it seems there is enough evidence to believe that physical characteristics at microhabitat scale produce major effects on macroinvertebrate distribution patterns. Relationships between macroinvertebrate taxa and hydraulic conditions at microhabitat scale could be also related to the availability of food resources. For example, molluscs may be related to lentic microhabitats because they are directly affected by hydraulic stress, as they are easily detached by rapid and turbulent flows, and also indirectly, because food availability (i.e. periphyton) is diminished in shallow and rapid flows (Clausen \& Biggs, 1997).

Another important physical characteristic determining macroinvertebrate microdistribution is substrate composition. For example, Oligochaeta and Ephemera are usually linked to the finest substrate sizes, while other taxa such as Perla are commonly related to coarser substrates (Giller \& Malmqvist, 1997). Beisel et al. (1998b), after analysing macroinvertebrate assemblages in substrates with different complexity (bedrock, bank roots and mosses) concluded that physical struc- ture and complexity at the microhabitat scale was crucial in determining macroinvertebrate number of taxa and individuals.

Similar results were reported by Larsen et al. (2009) with a subtle but important difference. As part of their study, they collected data on invertebrates and environmental attributes on the same streams at patch (small areas within riffles and glides) and reach scales (samples taken on riffles and glides along longer reaches). They then identified species assemblages at both scales and established correlations with environmental attributes. They found that communities defined at the scale of patches were strongly associated with local changes in depth, substrate size and flow velocity (representing differences in environmental conditions between samples taken from riffles and glides), whereas communities defined at reach level were correlated to larger scale attributes such as nitrates, catchment and riparian land uses (representing differences in environmental conditions between reaches). Thus, survey and sampling design choices can strongly influence the scale and nature of the relationships identified by the analyses. Species assemblages at the scale of mesohabitats may be very different from those at the scale of river reaches. In turn, this will have consequences on the scale of environmental attributes related to them. As illustrated by the previous example, it is likely that strong relationships will be found between environmental attributes and species assemblages defined at the same scale. The choice of scale for defining communities can therefore be problematic as there may not be any objective reasons for choosing one scale rather than another. In the end, the choice may have to be a pragmatic one based on the scale at which management is carried out and the priority given to various community types.

In summary, physical attributes at catchment scale explain some of the variability between macroinvertebrate assemblages although relationships seem stronger at lower spatial scales. Macroinvertebrate communities seem to be highly influenced by physical characteristics at the microhabitat scale, quite likely because of their relatively small size and reduced capacity of movement. Brosse et al. (2003) concluded 
that models based on just one level of the spatial scale are not able to produce good predictions of macroinvertebrate number of taxa, while models incorporating different scale levels simultaneously (physical variables from basin, reach and microhabitat) yielded better results. However, these findings may also be explained by methodological choices. The scale at which invertebrate communities are defined may indeed influence the strength of relationships to environmental attributes and affect the ability of environmental managers to identify pressures and impacts acting at larger or smaller scale. This may be an unavoidable consequence of methodological and practical choices that needs to be taken into account when doing data analysis.

\section{Riparian forest}

The riparian zone is the ecotone between aquatic and terrestrial ecosystems. Riparian communities have different compositions and phenologies than those present in rivers or on land. They are adapted to nutrient-rich environments with high water tables (Elosegui \& Sabater, 2009). Riparian plant communities are not homogeneous within the landscape. Their distribution, structure and abundance show patterns influenced by the biophysical environment at different scales (Gregory et al., 1991; Lyon \& Gross, 2005; Goebel et al., 2006; Merrill et al., 2006; Sarr \& Hibbs, 2007).

At basin scale, climate and geology are the main factors controlling riparian plant species composition and distribution (Sarr \& Hibbs, 2007). Species have different nutrient, water and temperature requirements influenced by a gradient of climatic and geologic conditions from headwaters to estuaries (Gregory et al., 1991). Harvey et al. (2008) found that bank vegetation complexity is greater for soft rock types, which tend to be more abundant in lowland low energy reaches. The downstream gradient of increasing valley width, increasing stream sinuosity and decreasing stream slope seems to heavily influence the structure of riparian communities (Merrill et al., 2006). The strength of the relationship between physical factors and riparian diversity is not homogeneous between riparian com- munity types, being weaker for shrubs than for trees (Lyon \& Gross, 2005).

At reach scale, the shape of the valley determines the composition and width of the riparian zone. Constrained river reaches present narrow valley floors with little geomorphic diversity and the vegetation on adjacent hill slopes is similar to upslope communities. Valley floors in unconstrained reaches are wider and topographically more diverse, allowing broad and complex riparian communities (Gregory et al., 1991). Although valley shape, sinuosity or stream gradient occur at coarse scales, they heavily influence the riparian environment at local scale because they determine the geomorphic structure of the riparian zone.

Local hydrological conditions (inter- and intra-annual water flow variability, water table depth and sediment flux) also influence riparian vegetation composition and structure. The intensity and frequency of floods decreases and the depth of the water table increases away from the channel (Lite et al., 2005). There is also a downstream longitudinal gradient in flood intensity but stream power can also peak at some locations due to local changes in slope and discharge (Bendix, 1997; Lite et al., 2005). Riparian plant species may therefore be spatially and temporally distributed according to their ability to withstand gradients of water and nutrient availability and flooding stress. As a consequence, riparian communities closer to the river tend to be composed of herbs and deciduous shrubs and trees of different ages with an abundance of younger stands, while communities further away tend to be older and composed of a mixture of riparian and upland species (Gregory et al., 1991). This pattern can change in active meandering channels where older riparian communities are found along the outer edge of meanders and saplings along the inside edge (Fonda, 1974; Gregory et al., 1991).

Riparian communities are not only influenced by fluvial processes and landforms. Upland (e.g. landslides, fire, wind, plant disease, insect outbreaks, herbivory) and river disturbances (e.g. floods, droughts) also determine the distribution and evolution of riparian vegetation (Gregory et al., 1991). Many of these disturbances create open spaces within the riparian forest that may 
be occupied by opportunistic and fast-growing plant species. Fire also changes soil properties allowing the establishment of fire adapted species. Moreover, the way in which riparian plants adapt to disturbance gradients is based on life history and reproductive strategy (Merritt et al., 2010). For example, stable riparian areas with little extreme floods favour perennial species with vegetative reproduction, while highly variable habitats favour sexual reproduction. Disturbance also affects plant morphology, so that plants inhabiting environments with highly variable surface and groundwater levels use different mechanisms, such as deeper and complex root systems, flexible stems or the capacity of reducing leaf size during drought periods. Thus, riparian vegetation can be grouped into functional groups or guilds characterised by traits that respond to disturbance regimes.

Riparian plant communities influence the physical habitat, but at lower spatial scales. Tabacchi et al. (2000) listed some of the most important hydro-geomorphic effects caused by riparian communities: (1) they interact with overbank flow, increasing flow resistance and inducing sediment deposition; when riparian forest disappears, river entrenchment increases and available stream habitat and lateral connectivity decrease (Sweeney et al., 2004); (2) they dissipate flood kinetic energy; (3) they act as an important functional buffer by trapping sediments thus reducing in-channel turbidity, scouring and abrasion; (4) they provide large woody debris to running waters, decreasing flow velocity and increasing sediment deposition upstream, as well as structure and complexity in the stream channel. In turn, large woody debris deposited out of channel during floods create a set of physical features in the riparian zone, such as areas of scour and plumes of fine sediment that increase riparian plant diversity (Francis et al., 2008); (5) finally, riparian roots increase substrate macroporosity, enhancing land drainage.

Riparian plant communities are therefore influenced by environmental attributes acting at a wide variety of scales over space and time from climate, geology to local hydrological processes. Riparian vegetation will also affect local processes and may regulate the level of erosion and deposition and the diversity and structure of instream habitats.

\section{Algae and macrophyte communities}

The spatial distribution of benthic algae is hierarchically organised. At large scale, geology, climate and biogeography control topography, slope, landuse and vegetation, which influence algae distribution at lower scales (Biggs, 1996; Stevenson, 1997).

Biggs (1996) distinguished between factors regulating processes of biomass accrual (light and nutrients) and those regulating processes of biomass loss (flood disturbance and grazing by macroinvertebrates and fish). Accrual processes and grazing dominate under medium to low flood disturbance frequency, and they operate at the substrate scale. At this scale, microtopography (Downes et al., 1998) and biotic competition are also important. The type of substrate exerts a strong influence in benthic algae, for example, determining diatom assemblage heterogeneity. Benthic diatom species grow on almost all stable substrata (Lowe \& Laliberte, 1996; Townsend \& Gell, 2005), such as rocks (epilithon), macroalgae or macrophytes (epiphytes), wood (epidendron), even sand (epipsammon) or mud (epipelon). Therefore, diatom community richness may be enhanced by substrate heterogeneity.

Bryophytes tolerate high flow velocities and heavy shade conditions typical of headwater streams better than vascular plants (Stream Bryophyte Group, 1999; Passauer et al., 2002). Moss cover is related to large substrate such as boulders or rocks (Cattaneo \& Fortin, 2000) and appear predominantly in upper and middle reaches. At micro-scale, bryophytes show a vertical zonation pattern across stream boulders, with species composition shifting along a gradient from permanently submerged to continuously exposed conditions (Virtanen et al., 2001). Species richness is commonly higher at or just above the water line, and it is highly influenced by movement or water level fluctuation (Muotka \& Virtanen, 1995).

Macrophyte communities are also influenced by a set of environmental factors acting at reach and microhabitat scales: water velocity, light, substrate, nutrient status and the presence of 
other species (i.e. competition). Whereas light, substrate and biological factors are considered to be major controls for the establishment and composition of macrophytes in lentic ecosystems, flow velocity is the primary factor controlling fluvial communities (Wilby et al., 1998; Franklin et al., 2008). Macrophyte growth is optimum at low to moderate flow velocities $\left(0.3-0.5 \mathrm{~m} \mathrm{~s}^{-1}\right)$ and decreases as flow velocity increases because of mechanical damage and uprooting (Riis \& Biggs, 2003; Franklin et al., 2008). The conditions surrounding optimal flow velocities (i.e. sediment stability, light availability) characterise low to medium river reaches.

Flow velocity, substrate, water level, light, nutrient status and competition are therefore important factors influencing the distribution and cover of aquatic vegetation. Vegetation distribution was long assumed to follow a longitudinal gradient, where primary production is limited by shading in the upper reaches and by depth and turbidity in the lower ones (Vannote et al., 1980). Although strong evidence of longitudinal zonation exist, rivers are now better described as mosaics of homogeneous habitat patches or mesohabitats (Cohen et al., 1998; Parasiewicz, 2001) defined according to their hydraulic and structural characteristics (Maddock, 1999; Brierley \& Fryirs, 2000; Thorp et al., 2006). In recent years, a series of studies started linking mesohabitats and aquatic vegetation. Okada and Watanabe (2002) studied the preference of filamentous green algae for shallow riffles, where light intensity and oxygen reached high levels and there was a continuous supply of nutrients. Kemp et al. (2002) found significant associations between the hydraulic conditions of runs and riffles with submerged, fine-leaved macrophytes and between the hydraulics of pool and glides with emergent and submerged, broad-leaved macrophytes.

Finally, river physical habitat can also be modified by aquatic vegetation, especially by macrophytes as their presence increases water resistance and depth, decreases water velocity and changes sediment dynamics (Green, 2006; Franklin et al., 2008). Macrophyte beds have also been shown to reduce bottom shear stress (James et al., 2004). Emergent plants seem to have a greater impact on velocities and sediment deposition than submerged fine/linear-leaved and submerged broad-leaved macrophytes (Clarke, 2002; Gurnell et al., 2006).

\section{Fish communities}

Fish communities have an important economic interest for humans (Annear et al., 2004) and a lot of research effort has been directed towards identifying the factors that affect fish distributions and population dynamics.

Of particular concern has been the estimation of available physical habitat in relation to environmental flows. The widespread use of quantitative methods to model physical stream habitat (e.g. Physical Habitat Simulation; Bovee \& Milhous, 1978) has led to the generation of important background knowledge about the influence of microhabitat characteristics on fish communities. These habitat models are based on the coupling of hydraulic habitat models and habitat suitability models for different species and life stages. Fish present significant differences in microhabitat use related to water velocity, depth, bottom hydraulic stress or substrate size (Heggenes, 1990; Bovee et al., 1998; MartinezCapel et al., 2009; Mouton et al., 2011). Thus the hydraulic component of the habitat is expected to influence species and population distribution between and within river reaches (Hynes, 1970; Bovee et al., 1998; Lamoroux et al., 1998). In addition, microhabitat conditions are particularly important during the spawning period as well as for egg development, hatching, alevin and fry survival rates. Most of these processes are related to riverbed stability, gravel substrate composition, permeability and the existence of shallow $(<15 \mathrm{~cm})$ nursery grounds (Parasiewicz, 2007; Enders et al., 2009).

Fish have also been studied at the scale of meso-habitats (i.e. riffle, rapid, glide, run, etc). Because of fish mobility, this scale may provide more realistic insights on their selection of physical habitats (Hardy \& Addley, 2001) at least for adults (Lobb \& Orth, 1991; Parasiewicz, 2001; Mouton et al., 2011). In addition, hydraulic conditions and refuge provided by ripar- 
ian vegetation, boulders or undercut banks within meso-scale units are also known to be important (Nestler, 1989; Dunbar, 2008).

Parasiewicz (2007) described mesohabitats as specific areas where the configuration of hydraulic patterns together with attributes that provide shelter, create favourable or unfavourable survival and development conditions for species and life stages. The presence of refuge areas during floods and droughts (Lowe et al., 2006) may determine the survival of species. For instance, fish species inhabiting steep-gradient intermittent stream reaches depend on the availability of hydrologically stable pools as refuge during periods of low flows (Chapman \& Kramer, 1991). Lowe et al. (2006) suggested that a higher mesohabitat type heterogeneity may strongly influence the presence or absence of some fish species in a river reach, implying that fish distribution is also driven by a wider habitat area than the mesohabitat (Dunbar, 2008).

At a wider scale, physical attributes such as altitude, distance from source, catchment area, slope or wetted width may control the upstream or downstream limit of species distribution along the river network (Schmutz \& Melcher, 2005). Downstream gradients in environmental conditions associated with changes in channel morphology and discharge can affect the structure and composition of fish communities (Lowe et al., 2006). Different authors (Morin \& Naiman, 1990; Santoul et al., 2004) showed that the number of fish species was negatively correlated with stream altitude. The literature supports the idea that altitude influences local fish species richness through water temperature (e.g. Huet, 1949) which regulates fish growth and fecundity (Gillet et al., 1995). Fish are also excluded from upper river reaches by natural physical barriers such as waterfalls and debris dams (Lowe et al., 2006) and also chemical barriers (Moran-Lopez et al., 2006). Water quality is an important factor in determining fish distribution at reach and larger scales (Beisel et al., 1998a; Arimoro et al., 2006; Maes et al., 2007; Alexandre et al., 2010; Hued et al., 2010). Slope is another key attribute influencing erosion and deposition processes, hydraulic characteristics and mesohabitat heterogeneity at reach scale (Santoul et al., 2004).

Finally, the presence of fish species in watersheds is also related to their life history (Townsend et al., 2003) as they have adapted to naturally occurring seasonal flow regimes, determined by the interaction between climate and geology (Annear et al., 2004). For instance, fish spawning preferentially in riffles do so during spring, when higher flows provide more riffle habitats (Aadland, 1993), so they are expected to be found in watersheds where climatic characteristics and geomorphological features converge to create those specific conditions. Growns (2006) found in a comparison of two rivers in Australia, that the spatial variation in fish community structure appeared to be similar between sites within reaches and between reaches within rivers, concluding that major differences between fish communities was mainly found at regional scale. Santoul (2004) found that although two communities from different hydroregions could differ in terms of species composition, they generally tend to have a similar number of species.

Fish geographical range can also be limited by their ability to migrate. Some fish species have extended their range by migrating but also through human intervention either by accident or in support of local fishing activity (Maitland \& Lyle, 1991). The presence of fish within reaches can also be strongly correlated to the presence of nearby populations. Local extinctions and recolonisations may therefore play an important role in the distribution and persistence of species/communities (Schlosser, 1995). Factors affecting migration such as weirs, sluices and dams may strongly influence species distribution and community structure (Maitland \& Lyle, 1991; Dynesius \& Nilsson, 1994).

Whilst attributes measured at similar scales may account for an important amount of the variation in community composition, it is likely that the precise nature of species assemblages is a consequence of combined effects from more than one scale. Other parameters difficult to take into account are biogeographical parameters linked to fish life or management history. 


\section{Summary}

Species and communities are related in complex ways to environmental attributes and scale.

The choice of scale at which communities are defined will affect the nature and scale of environmental attributes related to them. Like habitats, species assemblages can be defined at the micro, meso or macro-scale. There are not necessarily any objective reasons why one scale should be chosen rather than another. Often, communities are defined at the scale at which sampling and/or management are carried out and this may introduce an inherent and unavoidable bias in ecological monitoring.

Generally, the scale of habitats is proportional to the size and movement ability of the species considered. As many species go through a series of development stages, it is possible that they may relate to different scales and habitat features during their life cycles. Also, species/community occurrence may be affected by other factors such as the presence of barriers, water quality, physical modifications, competitors, predators or even nearby populations with similar assemblages.

From the study of correlations only, it is not clear what scale and environmental attributes to focus on although some present stronger relationships than others. Generally, it seems that the closer the link between the biology of species and environmental attributes, the stronger the relationship. However, not all statistical relationships can be explained in terms of cause and effect and it is not always clear why large-scale attributes such as altitude are correlated to fish. The reason can be that such attributes are indirectly linked to species distribution. Their action does not take place at the scale of the species but on a higher scale were they may affect environmental attributes directly linked to the organism. For example, slope may not affect fish species like trout or salmon directly, but may affect the occurrence of spawning gravels, the presence of silt detrimental to fish eggs, the distribution of channel vegetation acting as cover, the occurrence of pools and bank undercuts for resting adults, and the distribution of shallows for juveniles.

Understanding the exact nature of those relationships is paramount to a meaningful assess- ment of habitats and the development of restoration options. Ideally, one wants to target features and processes knowing the links of causality with species' life cycles in time and space. This implies that we have underlying assumptions on the way rivers function and interact with species and communities, i.e. we have a theoretical framework linking hydromorphology and ecology.

\section{THEORETICAL FRAMEWORK FOR DESCRIBING AND ASSESSING HABITATS}

The choice of theoretical framework is important as it will drive the choice of scale, attributes, survey and analytical methods used to investigate habitats and their quality (Guisan \& Thuiller, 2005). Modern fluvial ecological theory is the result of a gradual convergence of different disciplines: geography, hydrology, biology and ecology. The first formal attempt at linking all disciplines was made in 1980 by Vannote $e t$ al. through the development of the River Continuum Concept (RCC). The RCC postulates that biological communities are driven by continuous changes in physical conditions (e.g. width, depth, velocity etc) and the influence of geomorphic processes. The emphasis of the RCC is in studying how species composition responds to longitudinal variations in physical characteristics. The RCC spurned a debate that highlighted its major contribution -the linkage of geomorphology and biology-but also its limitations as many rivers do not display continua in physicochemical and biological processes (Statzner \& Higler, 1985; Perry \& Schaeffer, 1987; Rice et al., 2001). Some authors even suggested two complementary concepts to account for discontinuous changes in physical and biological assemblages: the Serial Discontinuity Concept (Ward \& Stanford, 1995) and the Link Discontinuity Concept (Rice et al., 2001). Nevertheless, the RCC had identified the first of four dimensions around which fluvial ecological theory would develop: longitudinal, lateral (channel-floodplain), vertical (channelgroundwater) and temporal (Ward, 1989).

Each dimension resulted in the development of new theoretical constructs. The study of nat- 
ural floodplain formation, physical structure and the exchange of water, nutrients, carbon and their impacts on biological communities led to the Flood Pulse Concept (Junk et al., 1989; Junk \& Wantzen, 2004). The presence of a layer connecting groundwater and surface water flows, the hyporheic zone, displaying specific physicochemical processes and invertebrate community generated the Hyporheic Corridor Concept (HCC) (Stanford \& Ward, 1993).

The RCC, FPC and HCC are complementary and assume that geomorphological processes within river systems reach points of equilibrium defining specific habitat conditions. This has led to the development of many typologies for characterising habitats (Rosgen, 1994; Montgomery \& Buffington, 1997; Ward et al., 2001; Church, 2002; Chessman et al., 2006). One important limitation of these concepts is in the lack of integration between biological and hydromorphological processes in space and time. There is an underlying assumption that geomorphology drives biology in a 'top-down' fashion (Newson \& Newson, 2000) when biology also influences morphological processes for example by reducing flow velocities and increasing bank strength in the case of riparian vegetation (Knighton, 1998; Champion \& Tanner, 2000; Clarke, 2002; Gurnell et al., 2006). As a consequence, habitats have often been defined at the spatial and temporal scale of the dominant geomorphological processes observed and not necessarily at the scale of the communities considered. Species may organise themselves along dominant physical gradients but they may also colonise niche habitats in discrete patches. Annual plant species such as Himalayan balsam colonise habitats (e.g. gravel bars) that are described as 'dynamic' at the temporal scale of the human observer but that could be described as in 'equilibrium' within the shorter life cycle of the species.

The 1980s were also the time when landscape ecology emerged as a discipline. The landscape ecology paradigm combined Hierarchy Theory and Patch Dynamics (Forman, 1995) in a new theoretical framework, Hierarchical Patch Dynamics (HPD) where the landscape was described as a hierarchy of habitat patches organ- ised in mosaics nested within each other $(\mathrm{Wu}$ \& Loucks, 1995). A catchment could thus be seen as a network of individual rivers, themselves organised in a mosaic of river segments each containing distinct habitat patches made of a juxtaposition of smaller patches and so on (Poole, 2002). Each level depends on processes acting at the level above and below. Morphological features/patterns could therefore be the result of top-down geomorphological processes but also bottom-up influences such as vegetation or biological activity (burrowing etc). Hierarchical Patch Dynamics assumes that the system is inherently dynamic in space and time, and therefore not stable, in equilibrium or organised along a continuum (Wu \& Loucks, 1995). However, depending on the spatial or temporal scale the system is observed at, it will display behaviours that can be described as 'stable' or in 'equilibrium' and may even appear to be organised as a continuum. As such, the HPD enables the integration of all previous concepts. It also delivers a templet for defining habitat that combines space and time in a way that is meaningful to species and those in charge of managing their habitats (Southwood, 1977; Townsend \& Hildrew, 1994; Newson \& Newson, 2000; Jansson et al., 2007; Lake et al., 2007). As long as the grain of observation is proportional to species space and time requirements (habitat size, migration distance, life cycle etc) one can derive meaningful insights on their ecology, link to river processes, impact of disturbance (natural, anthropogenic) viability and potential management actions. Finally, the Shifting Habitat Mosaic was introduced by Stanford et al. (2005) as an extension of the HPD to account for spacio-temporal shifts in the habitat mosaic due to flooding, erosion, deposition, woody debris and riparian vegetation.

\section{BUILDING CONCEPTUAL CAUSAL MODELS}

Once a theoretical framework has been chosen, we can start building hypotheses on the relationships between environmental attributes and species/communities in the shape of conceptual 
models. Information may be gathered from a variety of sources: scientific publications, books, grey literature, analysis of existing data, knowledge from scientists, experts and field practitioners from an outside the conservation organisations involved in implementing the WFD (Sear $e t$ al., 2009). An example of conceptual habitat model for trout spawning habitat can be seen in figure 1 .

This model was developed by English and Welsh Environment Agency experts and practitioners gathered together at a workshop with an ecologist and a geomorphologist. Prior to the meeting, a literature review was performed by one of the participants detailing existing knowledge on the relationship between habitat features, pressures and species. Participants were asked to produce conceptual models describing causal relationships between environmental factors and fish (Naura, unpublished data).

The model derived for trout spawning habitat includes features directly associated with or impacting on trout eggs. It also includes environmental attributes having an indirect impact through, for example, the removal of spawning gravel and changes to the hydraulic properties of the reach (e.g. resectioning). Not all attributes in this model are recorded/surveyed at the same scale. Some will be assessed at the level of mesohabitats (substrate size, riffles and runs), others will be assessed within the wider reach (poaching, tilled land, resectioning, impoundment, realignment, water quality) and some at the river or sub-catchment scale (abstraction and discharge). A single model can thus contain attributes act-

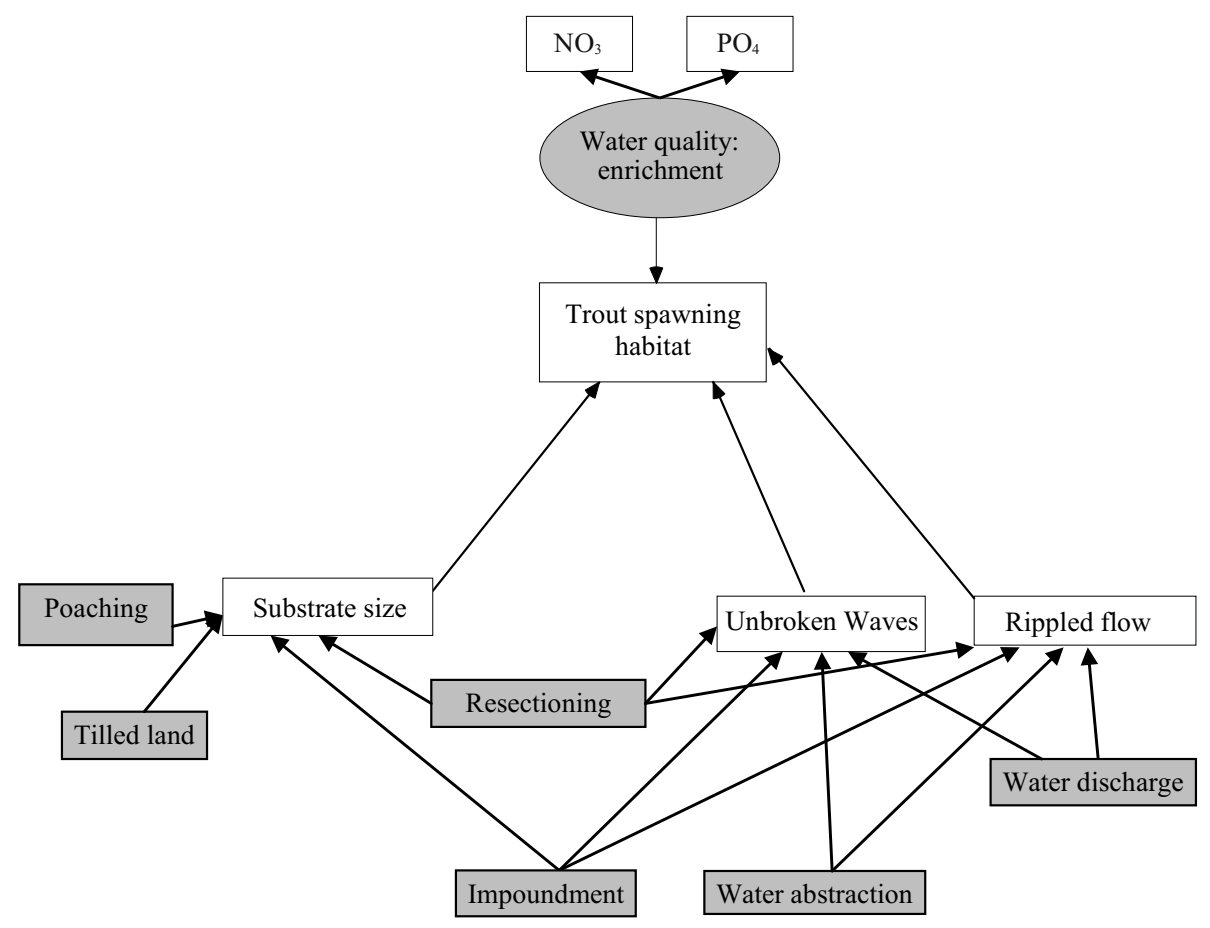

Figure 1. Conceptual model of trout spawning habitat (Naura, unpublished data). White boxes represent habitat features positively associated with trout. Grey boxes and circles represent pressures affecting trout or associated habitat features. Circles are factors or dimensions; they are characterised by indicator variables (boxes linked to circles by single arrows). Unbroken (standing) waves and rippled flow are flow types describing the regime (Froude number; Padmore et al., 1998). Single arrows show assumed causal relationships. Modelo conceptual de frezaderos de trucha (Naura, unpublised data). Los cuadrados blancos representan características del hábitat asociadas positivamente con la trucha. Los cuadrados y círculos grises representan presiones que afectan a la trucha o a características del hábitat. Los círculos representan factores o dimensiones que se encuentran caracterizados por variables indicadoras (cuadrados unidos a círculos por flechas únicas). Unbroken waves (olas no rompientes) y rippled flow (flujo ondulado) indican tipos de flujo que describen el régimen (Número de Froude; Padmore et al., 1998). Las flechas grises indican las relaciones asumidas como causales. 
ing at different scales. However, all attributes will have a significant impact on the features considered. Poaching and tilled land will introduce fines modifying substrate size and resectioning will remove coarser substrates. Abstractions and discharges will change flow depth and impact on flow regime. Resectioning will have a similar effect by increasing river width and decreasing flow depth and velocity profiles. Impoundments will cause deposition of fine substrates and increase water depth thus reducing flow roughness.

Such conceptual model can be tested statistically by using techniques such as Structural Equation Modelling (SEM) or Partial Least Square Path Modelling (PLS-PM). SEM and PLS-PM have been advocated as ways of testing theoretical models of complex phenomena. Using these techniques, it is possible to test the validity of relationships between individual variables or sets of variables acting as indicators for unknown latent dimensions (called latent variables) in complex causal models (Schumaker, 2004; Tenenhaus et al., 2005; Austin, 2007). SEM and PLS-PM differ on the way the analyses are performed. SEM is based on analysis of covariance whereas PLS-PM relies on analysis of variance. They both assume linearity. SEM works with normally distributed data, requires a larger sample sizes than PLS-PM and its use is mainly restricted to testing models rather than predicting new values. PLS-PM works on smaller sample sizes and can provide predictions for new data. However, it has been shown to be less accurate than SEM for testing hypotheses (Tenenhaus $e t$ $a l ., 2005)$. If theoretical relationships between attributes are known or assumed or if nonlinear effects can be expected, a Bayesian approach can be adopted to test the validity of the conceptual model (Borsuk et al., 2006).

The model in figure 1 can be further refined or expanded upon by developing additional models working at a finer or coarser scale. An example of a hierarchical model using Artificial Neural Networks can be found in Olden (2006). These models can help explain the links of causality between attributes working at different scales. It is important to note that such an approach only helps to test assumed causal links between attributes; it does not demonstrate causality. To do so, specific conditions have to be fulfilled (Kenny, 1979).

\section{CONCEPTUAL MODELS AS WORKING HYPOTHESES}

Once established, conceptual models can be used as working hypotheses for a series of purposes: (1) for identifying individual features and environmental attributes and the scale at which they should be measured or surveyed (i.e. for designing monitoring and survey protocols); (2) for testing the relationships on new data and deriving knowledge on ecological and catchment processes interactions; (3) for diagnosing environmental problems and identifying the scale and causes of observed disturbance; (4) for identifying at which scale management action should take place and designing habitat management schemes. Reichert et al. (2007) provide an example of how such framework can be used towards supporting river rehabilitation.

Within that framework, models embody existing knowledge and are working hypotheses that can be tested, refined and improved through the process of monitoring, diagnosing, managing (i.e. river restoration) and reviewing (i.e. river restoration scheme appraisal).

It is fundamentally a knowledge management process that has the advantage of combining theory, monitoring and management practice. It is potentially encompassing and inclusive as many different sources of knowledge can be used, from scientific literature to individual field experts. Uncertainty management is an integral part of the process: it is made explicit during model building and it is quantified at every iteration following data collection.

The framework implies that experts within and outside environmental organisations are chosen from a wide range of perspectives, bridging the gap between hydrology, geomorphology and ecology. Such conceptualisation would help integrate these disciplines and define testable hypotheses and models to direct data gathering and survey design (Vaughan et al., 2009). Attribute selection can then shift away from data mining 
techniques, and instead concentrate on establishing a network of causal links based on theory and identify those relationships that are meaningful within the conceptual framework. This would in turn enable to link data collection to the scale at which management can make a difference and appraise existing management practice. Further research would need to build a nested framework of hierarchical conceptual models describing the influence of each level on the levels below and above. The foundations for these models have already been laid out in the extensive geomorphological and ecological literature but would need to be formalised into models testable on existing data (Wheaton et al., 2004; Sear, 2010).

When little information is known on species biology and ecology, data mining techniques may be used in association with PLS-PM to generate potentially testable hypotheses and structural models (Jakobowicz \& Derquenne, 2007; $\mathrm{Wu}, 2010)$. Data partitioning practice or bootstrapping techniques should be used to eliminate potential spurious relationships (Vaughan \& Ormerod, 2005) and the results should be compared to the literature and expert knowledge. Monitoring followed by data analyses and river management in practice then provides the means of testing these hypotheses.

This assumes however, that there are structures in place within monitoring organisations that supervise the analysis of data and the acquisition and review of knowledge. The integration of expertise, monitoring, and science in an organisation within a knowledge management strategy could greatly benefit knowledge acquisition, dissemination and best practice. It would also reinstate scientists in their role of knowledge creators rather than the less satisfying, and often assumed, role of project manager.

\section{CONCLUSIONS}

Throughout this paper, we have been trying to avoid discussing the potentially long list of publications and findings relating species habitat features and geomorphological processes at different scales. Indeed, we felt it was more important to situate the debate within the framework of what we are trying to achieve and the theoretical assumptions we will take. These two issues are often ignored in the hurry surrounding the delivery of very challenging objectives, nonetheless they influence both the usefulness and validity of the data collected. The Water Framework Directive requires us to be able to assess, diagnose and remedy problems with river habitats. These requirements imply that we possess knowledge or have a way of gathering knowledge on all the processes that influence species and communities so that we can design adequate monitoring protocols targeting the right features, processes and disturbances at the right spatial and temporal scales.

Establishing or at least gathering evidence on causal links between habitats and species is essential to the assessment of river habitats and the delivery of effective management. The choice of feature, scale of study/survey is as much a practical as a theoretical issue. If we assume a landscape ecological perspective and consider the landscape as a mosaic of nested smaller mosaics, the scale at which features are chosen and assessed matters. Causal relationships will generally be found within the spatial and temporal scales of the organism but not always. Temperature may for example influence fish distribution across large geographical scales. Building models describing causal links between habitat features and species and features and processes across the hierarchy of landscape scale may represent an effective way of designing monitoring schemes and surveys.

Unfortunately, not enough is known about species and communities habitat requirements and it may take years before we can ascertain causal relationships between environmental attributes and species. The resources needed to gather such knowledge in the laboratory or in controlled large scale experiments are likely to be prohibitive and there is not guarantee that they will translate to the real environment.

Fortunately, knowledge exists in the head of many local experts and field practitioners. Provided an adequate framework for gathering data and knowledge is set up within conservation organisations, one can use monitoring as 
an opportunity for testing expert knowledge on species habitat relationships and gradually develop models describing the relationship between species/communities, habitats, river/catchment processes and pressures. We consider that by doing so, we will not only be able to create a virtuous cycle of knowledge acquisition within conservation organisations and promote evidence-based decision-making, but we will also build confidence and partnership between scientists, environmental practitioners, managers and politicians.

\section{REFERENCES}

AADLAND, L. P. 1993. Stream habitat types: Their fish assemblages and relationship to flow. North American Journal of fisheries Management, 13: 790-806.

ALEXANDRE, C. V., K. E. ESTEVES \& M. MELLO. 2010. Analysis of fish communities along a rural-urban gradient in a neotropical stream (Piracicaba River Basin, So Paulo, Brazil). Hydrobiologia, 641 (1): 97-114.

ANNEAR, T., I. CHISHOLM, H. BEECHER, A. LOCKE \& A. O. AUTHORS. 2004. Instream flows for riverine resource stewardship, revised edition, Cheyenne, WY.: Instream Flow Council.

ARGENT, D. G., J. A. BISHOP, J. STAUFFER, JAY R., R. F. CARLINE \& W. L. MYERS. 2003. Predicting freshwater fish distributions using landscape-level variables. Fisheries Research, 60 (1): 17-32.

ARIMORO, F. O., R. B. IKOMI \& E. C. OSALOR. 2006. The impact of sawmill wood wastes on the water quality and fish communities of Benin River, Niger Delta area, Nigeria. World Journal of Zoology, 1 (2): 94-102.

AUSTIN, M. 2007. Species distribution models and ecological theory: A critical assessment and some possible new approaches. Ecological Modelling, 200 (1-2): 1-19.

BEISEL, J.-N., P. USSEGLIO-POLATERA, S. THOMAS \& J. C. MORETEAU. 1998a. Stream community structure in relation to spatial variation: the influence of mesohabitat characteristics. Hydrobiologia, 389 (1): 73-88.

BEISEL, J.-N., P. USSEGLIO-POLATERA, S. THOMAS \& J. C. MORETEAU. 1998b. Stream community structure in relation to spatial variation: the influence of mesohabitat characteristics. Hydrobiologia, 389 73-88.

BENDA, L., N. L. POFF, D. MILLER, T. DUNNE, G. REEVES, G. PESS \& M. POLLOCK. 2004. The Network Dynamics Hypothesis: How Channel Networks Structure Riverine Habitats. Bioscience, 54(5): 413-427.

BENDIX, J. 1997. Flood disturbance and the distribution of riparian species diversity. Geographical Review, 87(4): 468-483.

BIGGS, B. J. F. 1996. Patterns in benthic algae of streams. In: Algal ecology: freshwater benthic ecosystems. R. J. Stevenson, M. L. Bothwell \& R. L. Lowe (eds.): 753 pp. Academic Press, San Diego.

BORSUK, M. E., P. REICHERT, A. PETER, E. SCHAGER \& P. BURKHARDT-HOLM. 2006. Assessing the decline of brown trout (Salmo trutta) in Swiss rivers using a Bayesian probability network. Ecological Modelling, 192 (1-2): 224-244.

BOVEE, K. D., B. L. LAMB, J. M. BARTHHOLOW, C. B. STALNAKER, J. TAYLOR \& J. HENRISKEN. 1998. Stream habitat analysis using the instream flow incremental methodology. U.S. Geological Survey, Biological Resources Division Information and Technology report USGS/BRD1998-0004. $131 \mathrm{pp}$.

BOVEE, K. D. \& R. MILHOUS. 1978. Hydraulic simulation in instream flow studies: Theory and techniques. Fish and Wildlife Service.156.

BRIERLEY, G. J. \& K. FRYIRS. 2000. River Styles, a geomorphic approach to catchment characterization: Implications for river rehabilitation in Bega catchment, New South Wales, Australia. Environmental Management, 25 (6): 661-679.

BROOKS, A. J., T. HAEUSLER, I. REINFELDS \& S. WILLIAMS. 2005. Hydraulic microhabitats and the distribution of macroinvertebrate assemblages in riffles. Freshwater Biology, 50: 331-344.

BROSSE, S., C. J. ARBUCKLE \& C. R. TOWNSEND. 2003. Habitat scale and biodiversity: influence of catchment, stream reach and bedform scales on local invertebrate diversity. Biodiversity and Conservation, 12(10): 2057-2075.

BUFFAGNI, A. \& E. COMIN. 2000. Secondary production of benthic communities at the habitat scale as a tool to assess ecological integrity in mountain streams. Hydrobiologia, 422/423 183-195.

CARTER, J. L., S. V. FEND \& S. S. KENNELLY. 1996. The relationships among three habitat scales and stream benthic invertebrate community structure. Freshwater Biology, 35(1): 109-124. 
CATTANEO, A. \& L. FORTIN. 2000. Moss distribution in streams of the Quebec Laurentian Mountains. Canadian Journal of Botany, 78(6): 748-752.

CHAMPION, P. D. \& C. C. TANNER. 2000. Seasonality of macrophytes and interaction with flow in a New Zealand lowland stream. Hydrobiologia, 441(1-3): 1-12.

CHAPMAN, L. J. \& D. L. KRAMER. 1991. The Consequences of Flooding for the Dispersal and Fate of Poeciliid Fish in an Intermittent Tropical Stream. Oecologia, 87(2): 299-306.

CHESSMAN, B. C., K. A. FRYIRS \& G. J. BRIERLEY. 2006. Linking geomorphic character, behaviour and condition to fluvial biodiversity: implications for river management. Aquatic ConservationMarine and Freshwater Ecosystems, 16(3): 267288.

CHURCH, M. 2002. Geomorphic thresholds in riverine landscapes. Freshwater Biology, 47(4): 541557.

CLARKE, S. J. 2002. Vegetation growth in rivers: influences upon sediment and nutrient dynamics. Progress in Physical Geography, 26(2): 159-172.

CLAUSEN, B. \& B. J. F. BIGGS. 1997. Relationships between benthic biota and hydrological indices in New Zealand streams. Freshwater Biology, 38: 327-342.

COHEN, P., H. ANDRIAMAHEFA \& J. G. WASSON. 1998. Towards a regionalization of aquatic habitat: distribution of mesohabitats at the scale of a large basin. Regulated Rivers: Research \& Management, 14(5): 391-404.

CORKUM, L. D. 1989. Patterns of Benthic Invertebrate Assemblages in Rivers of Northwestern North-America. Freshwater Biology, 21(2): 191205.

DEATH, R. G. \& M. K. JOY. 2004. Invertebrate community structure in streams of the ManawatuWanganui region, New Zealand: the roles of catchment versus reach scale influences. Freshwater Biology, 49: 982-997.

DOWNES, B. J., P. S. LAKE, A. GLAISTER \& J. A. WEBB. 1998. Scales and frequencies of disturbances: rock size, bed packing and variation among upland streams. Freshwater Biology, 40: 625-639.

DUNBAR, M. J. 2008. Mesoscale approaches for the quantification and modelling of fish habitat. Center for Ecology and Hydrology. Wallingford, UK.

DYNESIUS, M. \& C. NILSSON. 1994. Fragmentation and Flow Regulation of River Systems in the
Northern 3rd of the World. Science, 266(5186): 753-762.

EEDY, R. I. \& D. J. GIBERSON. 2007. Macroinvertebrate distribution in a reach of a north temperate eastern Canadian river: Relative importance of detritus, substrate and flow. Fundamental and Applied Limnology, 169(2): 101-114.

ELOSEGUI, A. \& S. SABATER. 2009. Conceptos y técnicas en ecología fluvial, Fundación BBVA. Bilbao. España. 444 pp.

ENDERS, E. C., D. A. SCRUTON \& K. D. CLARKE. 2009. The natural flow paradigm and Atlantic salmon-moving from concept to practice River Research and Applications, 25: 2-15.

EUROPEAN UNION. 1992. Council Directive 92/ 43/EEC on the conservation of natural habitats and of wild fauna and flora.

EUROPEAN UNION. 2000. Directive 2000/60/EC of the European Parliament and of the Council of 23 October 2000 establishing a framework for Community action in the field of water policy.

FEIST, B. E., E. A. STEEL, G. R. PESS \& R. E. BILBY. 2003. The influence of scale on salmon habitat restoration priorities. Animal Conservation, 6: 271-282.

FONDA, R. W. 1974. Forest succession in relation to river terrace development in Olympic National Park, Washington. Ecology, 55: 927-942.

FORMAN, R. T. T. 1995. Land Mosaics. The ecology of landscapes and regions, Cambridge University Press. Cambridge. 632 pp.

FRANCIS, R., P. TIBALDESCHI \& L. MCDOUGALL. 2008. Fluvially-deposited large wood and riparian plant diversity. Wetlands Ecology and Management, 16(5): 371-382.

FRANKLIN, P., M. DUNBAR \& P. WHITEHEAD. 2008. Flow controls on lowland river macrophytes: A review. Science of the Total Environment, 400(13): 369-378.

FRISSELL, C. A., W. J. LISS, C. E. WARREN \& M. D. HURLEY. 1986. A hierarchical framework for stream habitat classification: Viewing streams in a watershed context. Environmental Management, 10(2): 199-214.

GILLER, P. S. \& B. MALMQVIST. 1997. The Biology of Streams and Rivers, M. J. Crawley, C. Little, T. R. E. Southwood \& S. Ulfstrand ed, Oxford, England: Oxford University Press. 286 pp.

GILLET, C., J. P. DUBOIS \& S. BONNET. 1995. Influence of Temperature and Size of Females on the Timing of Spawning of Perch, Perca-Fluviatilis, in 
Lake Geneva from 1984 to 1993. Environmental Biology of Fishes, 42(4): 355-363.

GOEBEL, P. C., K. S. PREGITZER \& B. J. PALIK. 2006. Landscape hierarchies influence riparian ground-flora communities in Wisconsin, USA. Forest Ecology and Management, 230: 43-54.

GREEN, J. C. 2006. Effect of macrophyte spatial variability on channel resistance. Advances in Water Resources, 29(3): 426-438.

GREGORY, S. V., F. J. SWANSON, W. A. MCKEE \& K. W. CUMMINS. 1991. An Ecosystem Perspective of Riparian Zones. Bioscience, 41(8): 540551.

GROWNS, I., K. ASTLES \& P. GEHRKE. 2006. Multiscale spatial and small-scale temporal variation in the composition of riverine fish communities. Environmental Monitoring and Assessment, 114(1-3): 553-571.

GUISAN, A. \& W. THUILLER. 2005. Predicting species distribution: offering more than simple habitat models. Ecology Letters, 8(9): 993-1009.

GURNELL, A. M., M. P. VAN OOSTERHOUT, B. DE VLIEGER \& J. M. GOODSON. 2006. Reachscale interactions between aquatic plants and physical habitat: River Frome, Dorset. River Research and Applications, 22(6): 667-680.

HARDY, T. B. \& R. C. ADDLEY. 2001. Vertical integration of spatial and hydraulic data for improved habitat modelling using geographic information systems. Hydro-Ecology: Linking Hydrology and Aquatic Ecology, 266: 65-75.

HARVEY, G. L., A. M. GURNELL \& N. J. CLIFFORD. 2008. Characterisation of river reaches: The influence of rock type. Catena, 76(1): 78-88.

HEGGENES, J. 1990. Habitat utilization and preferences in juvenile atlantic salmon (salmo salar) in streams. Regulated Rivers: Research \& Management, 5(4): 341-354.

HEINO, J., T. MUOTKA \& R. PAAVOLA. 2003. Determinants of macroinvertebrate diversity in headwater streams: regional and local influences. Journal of Animal Ecology, 72(3): 425-434.

HUED, A. C., S. DARDANELLI \& M. A. BISTONI. 2010. Temporal and spatial variability of fish assemblages in a river basin with an environmental degradation gradient. Community Ecology, 11(1): 41-50.

HUET, M. 1949. Aperçu des relations entre la pente et les populations piscicoles des eaux courantes. Revue Suisse d' Hydrololgie, 11: 332-351.
HYNES, H. B. 1970. The Ecology of Running Waters. University of Toronto press. Toronto. $555 \mathrm{pp}$.

JAKOBOWICZ, E. \& C. DERQUENNE. 2007. A modified PLS path modeling algorithm handling reflective categorical variables and a new model building strategy. Computational Statistics \& Data Analysis, 51(8): 3666-3678.

JAMES, W. F., J. W. BARKO \& M. G. BUTLER. 2004. Shear stress and sediment resuspension in relation to submersed macrophyte biomass. Hydrobiologia, 515(1-3): 181-191.

JANSSON, R., C. NILSSON \& B. MALMQVIST. 2007. Restoring freshwater ecosystems in riverine landscapes: the roles of connectivity and recovery processes. Freshwater Biology, 52(4): 589-596.

JUNK, W. J., P. B. BAYLEY \& R. E. SPARKS. 1989. The flood pulse concept in river-floodplain systems. Proceedings of the International Large Rivers Symposium (LARS). Bangkok, Thailand 110-127.

JUNK, W. J. \& K. M. WANTZEN. 2004. The Flood Pulse Concept: new aspects, approaches, and applications-an update. Proceedings of the 2nd International Symposium on the Management of Large Rivers for Fisheries, Bangkok, Thailand 117-149.

KEMP, J. L., D. M. HARPER \& G. A. CROSA. 2002. A deeper understanding of river habitat-scale ecohydraulics: Interpreting the relationship between habitat type, depth and velocity using knowledge of sediment dynamics and macrophyte growth. Ecohydrology and Hydrobiology, 2(1-4): 271-282.

KENNY, D. A. 1979. Correlation and causality, John Wiley and Sons. 294 pp.

KNIGHTON, D. 1998. Fluvial forms and processes-A new perspective, Arnold. London. UK. 383 pp.

LAKE, P. S., N. BOND \& P. REICH. 2007. Linking ecological theory with stream restoration. Freshwater Biology, 52(4): 597-615.

LAMOROUX, N., H. CAPRA \& M. POUILLY. 1998. Predicting Habitat suitability for lotic fish: Linking statistical hydraulic models with multivariate habitat use models. Regulated River: Research \& Management, 14(1): 1-11.

LARSEN, S., I. P. VAUGHAN \& S. J. ORMEROD. 2009. Scale-dependent effects of fine sediments on temperate headwater invertebrates. Freshwater Biology, 54(1): 203-219.

LI, J., A. HERLIHY, W. GERTH, P. KAUFMANN, S. GREGORY, S. URQUHART \& D. P. LARSEN. 2001. Variability in stream macroinvertebrates at 
multiple spatial scales. Freshwater Biology, 46: 87-97.

LITE, S. J., K. J. BAGSTAD \& J. C. STROMBERG. 2005. Riparian plant species richness along lateral and longitudinal gradients of water stress and flood disturbance, San Pedro River, Arizona, USA. Journal of Arid Environments, 63(4): 785-813.

LOBB, M. D. \& D. J. ORTH. 1991. Habitat Use by an Assemblage of Fish in a Large Warmwater Stream. Transactions of the American Fisheries Society, 120(1): 65-78.

LOWE, R. \& G. D. LALIBERTE. 1996. Benthic stream algae: distribution and structure. In: Stream Ecology. R. Hauer \& G. A. Lamberti (eds.): 269293. Academic Press, California. USA.

LOWE, W. H., G. E. LIKENS \& M. E. POWER. 2006. Linking scales in stream ecology. Bioscience, 56(7): 591-597.

LYON, J. \& N. M. GROSS. 2005. Patterns of plant diversity and plant-environmental relationships across three riparian corridors. Forest Ecology and Management, 204(2-3): 267-278.

MADDOCK, I. 1999. The importance of physical habitat assessment for evaluating river health. Freshwater Biology, 41(2): 373-391.

MADSEN, T. V. \& N. CEDERGREEN. 2002. Sources of nutrients to rooted submerged macrophytes growing in a nutrient-rich stream. Freshwater Biology, 47(2): 283-291.

MAES, J., M. STEVENS \& J. BREINE. 2007. Modelling the migration opportunities of diadromous fish species along a gradient of dissolved oxygen concentration in a European tidal watershed. Estuarine Coastal and Shelf Science, 75(1-2): 151162.

MAITLAND, P. S. \& A. A. LYLE. 1991. Conservation of freshwater fish in the British Isles: The current status and biology of threatened species. Aquatic Conservation: Marine and Freshwater Ecosystems, 1(1): 25-54.

MANN, R. H. K. \& J. A. B. BASS. 1997. The critical water velocities of larval roach (Rutilus rutilus) and dace (Leuciscus leuciscus) and implications for river management. Regulated Rivers-Research \& Management, 13(3): 295-301.

MARTINEZ-CAPEL, F., D. G. DE JALON, D. WERENITZKY, D. BAEZA \& M. RODILLAALAMA. 2009. Microhabitat use by three endemic Iberian cyprinids in Mediterranean rivers (Tagus River Basin, Spain). Fisheries Management and Ecology, 16(1): 52-60.
MCRAE, S. E., J. D. ALLAN \& J. B. BURCH. 2004. Reach and catchment-scale determinants of the distribution of freshwater mussels (Bivalvia: Unionidae) in south-eastern Michigan, USA. Freshwater Biology, 49(2): 127-142.

MERIGOUX, S. \& S. DOLEDEC. 2004. Hydraulic requirements of stream communities: a case study on invertebrates. Freshwater Biology, 49(5): 600613.

MERRILL, A. G., T. L. BENNING \& J. A. FITES. 2006. Factors controlling structural and floristic variation of riparian zones in a mountainous landscape of the western United States. Western North American Naturalist, 66(2): 137-154.

MERRITT, D. M., M. L. SCOTT, N. L. POFF, G. T. AUBLE \& D. A. LYTLE. 2010. Theory, methods and tools for determining environmental flows for riparian vegetation: riparian vegetation-flow response guilds. Freshwater Biology, 55(1): 206225.

MONTGOMERY, D. R. \& J. M. BUFFINGTON. 1997. Channel-reach morphology in mountain drainage basins. Geological Society of America Bulletin, 109(5): 596-611.

MORAN-LOPEZ, R., E. DA SILVA, J. L. PEREZBOTE \& C. C. AMADO. 2006. Associations between fish assemblages and environmental factors for Mediterranean-type rivers during summer. Journal of Fish Biology, 69(5): 1552-1569.

MORIN, R. \& R. J. NAIMAN. 1990. The relation of stream order to fish scommuit dynamics in boreal forest watershed. Polskie Archiwum Hydrobiologii, 37: 135-150.

MOUTON, A. M., J. D. ALCARAZ-HERNANDEZ, B. DE BAETS, P. L. M. GOETHALS \& F. MARTINEZ-CAPEL. 2011. Data-driven fuzzy habitat suitability models for brown trout in Spanish Mediterranean rivers. Environmental Modelling \& Software, 26(5): 615-622.

MUOTKA, T. \& R. VIRTANEN. 1995. The stream as a habitat templet for bryophytes: species distributions along gradients in disturbance and substratum heterogeneity. Freshwater Biology, 33: 141160.

NAURA, M. 2005. Decision support tools for biodiversity Phase I. Environment Agency. 70 pp.

NESTLER, J. M. 1989. Instream habitat modelling techniques. In: Alternatives in Regulated River Managment. J. A. Gore \& G. E. Petts (eds.): 295315. CRC Press., Boca Ratón, FL. 
NEWSON, M. D. \& C. L. NEWSON. 2000. Geomorphology, ecology and river channel habitat: mesoscale approaches to basin-scale challenges. Progress in Physical Geography, 24(2): 195-217.

OKADA, H. \& Y. WATANABE. 2002. Effect of physical factors on the distribution of filamentous green algae in the Tama River. Limnology, 3(2): 121126.

OLDEN, J. D., N. L. POFF \& B. P. BLEDSOE. 2006. Incorporating ecological knowledge into ecoinformatics: An example of modeling hierarchically structured aquatic communities with neural networks. Ecological Informatics, 1(1): 33-42.

PADMORE, C. L., M. D. NEWSON\& M. E. CHARLTON. 1998. Instream habitat in gravel bed rivers: identification and characterisation of biotopes. In: Gravel bed rivers in the environment. P. C. Klingeman, R. L. Beschta, P. D. Komar \& J. B. Bradley (eds.): 345-364. Highlands Ranch, CO: Water Resources Publications.

PARASIEWICZ, P. 2001. MesoHABSIM: A concept fot application of instream flow models in river restoration planning. Fisheries, 26(9): 6-13.

PARASIEWICZ, P. 2001. The MesoHABSIM model revisited. River Research and Applications, 23: 893-903.

PASSAUER, B., P. MEILINGER, A. MELZER \& S. SCHNEIDER. 2002. Does the structural quality of running waters affects the occurrence of macrophytes? Acta Hydrochimica Et Hydrobiologica, 30(4): 197-206.

PERRY, J. A. \& D. J. SCHAEFFER. 1987. The Longitudinal Distribution of Riverine Benthos-a River Dis-Continuum. Hydrobiologia, 148(3): 257-268.

POOLE, G. C. 2002. Fluvial landscape ecology: addressing uniqueness within the river discontinuum. Freshwater Biology, 47(4): 641-660.

PULLIN, A. S. \& T. M. KNIGHT. 2001. Effectiveness in conservation practice: Pointers from medicine and public health. Conservation Biology, 15(1): 50-54.

PULLIN, A. S. \& T. M. KNIGHT. 2005. Assessing conservation management's evidence base: a survey of management-plan compilers in the United Kingdom and Australia. Conservation Biology, 19(6): 1989-1996.

PULLIN, A. S., T. M. KNIGHT, D. A. STONE \& K. CHARMAN. 2004. Do conservation managers use scientific evidence to support their decisionmaking? Biological Conservation, 119(2): 245-252.
RATHERT, D., D. WHITE, J. C. SIFNEOS \& R. M. HUGHES. 1999. Environmental correlates of species richness for native freshwater fish in Oregon, USA. Journal of Biogeography, 26(2): $257-$ 273.

REICHERT, P., M. BORSUK, M. HOSTMANN, S. SCHWEIZER, C. SPORRI, K. TOCKNER \& B. TRUFFER. 2007. Concepts of decision support for river rehabilitation. Environmental Modelling \& Software, 22(2): 188-201.

RICE, S. P., M. T. GREENWOOD \& C. B. JOYCE. 2001. Tributaries, sediment sources, and the longitudinal organisation of macroinvertebrate fauna along river systems. Canadian Journal of Fisheries and Aquatic Sciences, 58(4): 824-840.

RICHARDS, C., R. J. HARO, L. B. JOHNSON \& G. E. HOST. 1997. Catchment and reach-scale properties as indicators of macroinvertebrate species traits. Freshwater Biology, 37(1): 219-xxx.

RICHARDS, C., L. B. JOHNSON \& G. E. HOST. 1996. Landscape-scale influences on stream habitats and biota. Canadian Journal of Fisheries and Aquatic Sciences, 53: 295-311.

RIIS, T. \& B. J. F. BIGGS. 2003. Hydrologic and hydraulic control of macrophyte establishment and performance in streams. Limnology and Oceanography, 48(4): 1488-1497.

ROSGEN, D. L. 1994. A Classification of Natural Rivers. Catena, 22(3): 169-199.

SAGNES, P., S. MERIGOUX \& N. PERU. 2008. Hydraulic habitat use with respect to body size of aquatic insect larvae: Case of six species from a French Mediterranean type stream. Limnologica, 38(1): 23-33.

SANCHEZ-MONTOYA, M. M., T. PUNTI, M. L. SUAREZ, M. D. VIDAL-ABARCA, M. RIERADEVALL, J. M. POQUET, C. ZAMORAMUNOZ, S. ROBLES, M. ALVAREZ, J. ALBATERCEDOR, M. TORO, A. M. PUJANTE, A. MUNNE \& N. PRAT. 2007. Concordance between ecotypes and macroinvertebrate assemblages in Mediterranean streams. Freshwater Biology, 52: 2240-2255.

SANTOUL, F., A. SOULARD, J. FIGUEROLA, R. CEREGHINO \& S. MASTRORILLO. 2004. Environmental factors influencing local fish species richness and differences between hydroregions in south-western France. International Review of Hydrobiology, 89(1): 79-87.

SARR, D. \& D. HIBBS. 2007. Woody riparian plant distributions in western Oregon, USA: comparing 
landscape and local scale factors. Plant Ecology, 190(2): 291-311.

SCHLOSSER, I. J. 1995. Critical Landscape Attributes That Influence Fish Population-Dynamics in Headwater Streams. Hydrobiologia, 303(1-3): 7181.

SCHMUTZ, S. \& A. MELCHER. 2005. Predicting reference fish communities of European rivers. Coast 626 European Aquatic Modelling Network, Silkeborg, Denmark.

SCHUMAKER, R. G. L. 2004. A beginners guide to structural equation modelling. Second edition, London Lawrence Erlbaum Associates. London. $498 \mathrm{pp}$

SEAR, D., M. NEWSON, C. HILL, J. OLD \& J. BRANSON. 2009. A method for applying fluvial geomorphology in support of catchment-scale river restoration planning. Aquatic ConservationMarine and Freshwater Ecosystems, 19(5): 506519.

SEAR, D. A. 2010. Integrating science and practice for the sustainable management of In-channel salmonid habitat. In: Salmonid Fisheries: Freshwater habitat management. P. S. Kemp (ed.) 81119. Wiley-Blackwell, Chichester.

SOUTHWOOD, T. R. E. 1977. Habitat, the Templet for Ecological Strategies? Journal of Animal Ecology, 46(2): 337-365.

STANFORD, J. A., M. S. LORANG \& F. R. HAUER. 2005. The shifting habitat mosaic of river ecosystems. International Association of Theoretical and Applied Limnology, 29: 123-136.

STANFORD, J. A. \& J. V. WARD. 1993. An Ecosystem Perspective of Alluvial Rivers-Connectivity and the Hyporheic Corridor. Journal of the North American Benthological Society, 12(1): 48-60.

STATZNER, B. \& B. HIGLER. 1985. Questions and Comments on the River Continuum Concept. Canadian Journal of Fisheries and Aquatic Sciences, 42(5): 1038-1044.

STEVENSON, R. J. 1997. Scale-dependent determinants and consequences of benthic algal heterogeneity. Journal of the North American Benthological Society, 16(1): 248-262.

STRAHLER, A. N. 1957. Quantitative analysis of watershed geomorphology. Transactions of the American Geophysicists Union, 38: 913-920.

STREAM BRYOPHYTE GROUP. 1999. Roles of Bryophytes in Stream Ecosystems. Journal of the North American Benthological Society, 18(2): 151-184
SUTHERLAND, W. J., S. ARMSTRONG-BROWN, P. R. ARMSWORTH, T. BRERETON, J. BRICKLAND, C. D. CAMPBELL, D. E. CHAMBERLAIN, A. I. COOKE, N. K. DULVY, N. R. DUSIC, M. FITTON, R. P. FRECKLETON, H. C. J. GODFRAY, N. GROUT, H. J. HARVEY, C. HEDLEY, J. J. HOPKINS, N. B. KIFT, J. KIRBY, W. E. KUNIN, D. W. MACDONALD, B. MARKER, M. NAURA, A. R. NEALE, T. OLIVER, D. OSBORN, A. S. PULLIN, M. E. A. SHARDLOW, D. A. SHOWLER, P. L. SMITH, R. J. SMITHERS, J. L. SOLANDT, J. SPENCER, C. J. SPRAY, C. D. THOMAS, J. THOMPSON, S. E. WEBB, D. W. YALDEN \& A. R. WATKINSON. 2006. The identification of 100 ecological questions of high policy relevance in the UK. Journal of Applied Ecology, 43(4): 617-627.

SUTHERLAND, W. J., A. S. PULLIN, P. M. DOLMAN \& T. M. KNIGHT. 2004. The need for evidence-based conservation. Trends in Ecology \& Evolution, 19(6): 305-308.

SWEENEY, B. W., T. L. BOTT, J. K. JACKSON, L. A. KAPLAN, J. D. NEWBOLD, L. J. STANDLEY, W. C. HESSION \& R. J. HORWITZ. 2004. Riparian deforestation, stream narrowing, and loss of stream ecosystem services. Proceedings of the National Academy of Sciences of the United States of America, 101(39): 14132-14137.

TABACCHI, E., L. LAMBS, H. GUILLOY, A. M. PLANTY-TABACCHI, E. MULLER \& H. DECAMPS. 2000. Impacts of riparian vegetation on hydrological processes. Hydrological Processes, 14(16-17): 2959-2976.

TENENHAUS, M., V. E. VINZI, Y. M. CHATELIN \& C. LAURO. 2005. PLS path modeling. Computational Statistics \& Data Analysis, 48(1): 159205.

THORP, J. H., M. C. THOMS \& M. D. DELONG. 2006. The riverine ecosystem synthesis: biocomplexity in river networks across space and time. River Research and Applications, 22(2): 123-147.

TOWNSEND, C. R., S. DOLEDEC, R. NORRIS, K. PEACOCK \& C. ARBUCKLE. 2003. The influence of scale and geography on relationships between stream community composition and landscape variables: description and prediction. Freshwater Biology, 48(5): 768-785.

TOWNSEND, C. R. \& A. G. HILDREW. 1994. Species traits in relation to a habitat templet for river systems. Freshwater Biology, 31(3): 265275. 
TOWNSEND, S. A. \& P. A. GELL. 2005. The Role of Substrate Type on Benthic Diatom Assemblages in the Daly and Roper Rivers of the Australian Wet/Dry Tropics. Hydrobiologia, 548(1): 101-115.

VANNOTE, R. L., G. W. MINSHALL, K. W. CUMMINS, J. R. SEDELL \& C. E. CUSHING. 1980. The river continuum concept. Canadian Journal of Fisheries and Aquatic Sciences, 37(1): 130-137.

VAUGHAN, I. P., M. DIAMOND, A. M. GURNELL, K. A. HALL, A. JENKINS, N. J. MILNER, L. A. NAYLOR, D. A. SEAR, G. WOODWARD \& S. J. ORMEROD. 2009. Integrating ecology with hydromorphology: a priority for river science and management. Aquatic Conservation-Marine and Freshwater Ecosystems, 19(1): 113-125.

VAUGHAN, I. P. \& S. J. ORMEROD. 2005. The continuing challenges of testing species distribution models. Journal of Applied Ecology, 42(4): 720730.

VIRTANEN, R., T. MUOTKA \& M. SAKSA. 2001. Species richness-standing crop relationship in stream bryophyte communities: patterns across multiple scales. Journal of Ecology, 89(1): 14-20.

WARD, J. V. 1989. The 4-Dimensional Nature of Lotic Ecosystems. Journal of the North American Benthological Society, 8(1): 2-8.

WARD, J. V. \& J. A. STANFORD. 1995. The Serial Discontinuity Concept-Extending the Model to
Floodplain Rivers. Regulated Rivers-Research \& Management, 10(2-4): 159-168.

WARD, J. V., K. TOCKNER, U. UEHLINGER \& F. MALARD. 2001. Understanding natural patterns and processes in river corridors as the basis for effective river restoration. Regulated RiversResearch \& Management, 17(6): 311-323.

WHEATON, J. M., G. B. PASTERNACK \& J. E. MERZ. 2004. Spawning habitat rehabilitation-I. Conceptual approach and methods. International Journal of River Basin Management, 2(1): 3-20.

WIENS, J. A. 2002. Predicting species occurrences: progress, problems, and prospects. In: Predicting Species Occurrences: Issues of Accuracy and Scale. J. M. Scott, P. J. Heglund, M. L. Morrison, J. B. Haufler, M. G. Raphael, W. A. Wall \& F. B. Samson (eds.): 739-749. Island Press, Covello.

WILBY, R. L., L. E. CRANSTON \& E. J. DARBY. 1998. Factors Governing Macrophyte Status in Hampshire Chalk Streams: Implications for Catchment Management. Water and Environment Journal, 12(3): 179-187.

WU, J. \& O. L. LOUCKS. 1995. From Balance of Nature to Hierarchical Patch Dynamics: A Paradigm Shift in Ecology. The Quarterly Review of Biology, 70(4): 439-466.

WU, W. W. 2010. Linking Bayesian networks and PLS path modeling for causal analysis. Expert Systems with Applications, 37(1): 134-139. 